\title{
Study of Probiotic Attributes of two ISOLATES Bacillus AERIUS and Bacillus CEREUS
}

\author{
Lavanya Ananthanarayanan ${ }^{a, b}$, Aparna Dubhashi ${ }^{a, *}$ \\ Dept. of Microbiology, Guru Nanak Khalsa College, Matunga (E), Maharashtra, India. \\ *avdubhashi@rediffmail.com, ${ }^{b}$ lavanyaananth10@gmail.com
}

\begin{abstract}
This article discusses about the various growth parameters of B.aerius and B.cereus in context of their probiotic capabilities. The optimum temperature for growth for the isolates was $37^{\circ} \mathrm{C}$ and $45^{\circ} \mathrm{C}$ respectively and $\mathrm{pH} 6$ for both. The isolates sporulated efficiently in a nutrient depleted medium. B.cereus was non hemolytic in nature while B.aerius was rendered non hemolytic. Tolerance to gastric acidity and bile salts is considered as an important factor for the probiotic to exert beneficial health effects. Resistance to $\mathrm{pH} 2-3 \mathrm{was}$ observed for both the isolates with the ability of $\mathrm{B}$. aerius spores to germinate at $\mathrm{pH}$ 3. Also the spores could tolerate bile salt concentration up to $2 \%$, with an ability to germinate at lower concentration. The present study thus proves the probiotic potential of both the Bacillus species.
\end{abstract}

Keywords: Acid and Bile salt tolerance, Sporulation Efficiency, Probiotics, B.aerius, B.cereus

\section{INTRODUCTION}

Probiotics are dietary supplements which contain potentially beneficial bacteria or yeast which reduce the risk of colonization by pathogenic bacteria thus avoiding any disturbances in the normal flora in the host body [1]. Several microorganisms can pass live through the human gastro intestinal tract. The concentrations of exogenous living microorganisms at the different levels of the gut are more significant variables than the overall percentage of survival. However, it seems that the main factor governing upper and lower small intestine and fecal concentrations of an exogenous strain is its resistance to upper digestive tract secretions [2].

Certain strains of Bacillus have been used for probiotic purpose [3,4]. The probiotic bacteria given through oral supplements on ingestion have to pass through the acidic $\mathrm{pH}$ of the gastrointestinal tract and as well encounter the bacteriocins or any antagonistic proteins or elevated osmolarity, oxygen starvation, nutrient competition, the immune response and exposure to a number of different potentially toxic compounds such as bile and degradative enzymes. Thus very few are available for colonization in the gut $[2,5]$. In order to exert their functional properties, probiotics need to be delivered to the desired sites in an active and viable form. The viability and activity of probiotics have been frequently cited as a prerequisite for achieving health benefits. For efficacy, it is recommended that probiotic bacteria should be delivered in high numbers (more than $10^{7}$ cells per milliliter or per gram of the product) [6]. One of the most important criteria for the potential of a probiotic strain is to overcome and resist the gastric environment and the presence of bile salts [7].

The genus Bacillus comprises a diverse collection of aerobic endospore-forming bacteria. Their structural organization of the spores makes them extremely resistant to external physical and chemical insults and in part determines their survival and exceptional longevity in the environment $[8,9]$. A few Bacillus species are currently being used as human and animal probiotics. The administration of spores as feed additives as opposed to vegetative cells clearly distinguishes Bacillus probiotics from other bacterial probiotic formulations and offers advantages such as ease of preparation, resistance to production processes, and extended shelf-life over a wide range of temperatures [10].

The objective of this study is to determine the growth and survival abilities of the 2 soil isolates Bacillus aerius and Bacillus cereus that have antibiotic effect against various human, poultry and aqua pathogens and are producers of various digestive enzymes and Vitamin $B_{12}$ [11] and also to ascertain their potential for commercial probiotic production. 


\section{Materials AND Methods}

\subsection{Temperature and $\mathrm{pH}$ Study}

Effect of incubation temperature on growth of B.aerius \& B.cereus was studied using Nutrient Broth (Hi-media) inoculated with $10^{6}$ cells $/ \mathrm{ml}$. incubation was carried out at $10^{\circ} \mathrm{C}, 25^{\circ} \mathrm{C}, 37^{\circ} \mathrm{C}, 45^{\circ} \mathrm{C}$ and $60^{\circ} \mathrm{C}$ temperature under orbital shaking conditions at $150 \mathrm{rpm}$ for $24 \mathrm{hr}$. Growth was measured in terms of Optical density at 550nm using Systronics photoelectric colorimeter 113.

Similarly the effect of pH was studied using Nutrient Broth (Hi-media) adjusted to $\mathrm{pH}$ 2,4,6,8 and 10. The temperature of incubation used for both the isolates was as per the earlier experiment respectively.

\subsection{Growth Curve}

Washed cells of overnight cultures were inoculated in nutrient broth with an O.D $D_{550 \mathrm{~nm}}$ adjusted to 0.05 $\left(\mathrm{T}_{0}\right)$. The flasks were incubated at $37^{\circ} \mathrm{C}$ in an orbital shaker at $150 \mathrm{rpm}$ and optical density read every half hour interval till a constant reading was obtained.

\subsection{Sporulation efficiency [10]}

Sporulation of the vegetative cells was induced by exhaustion in DSM broth [Nutrient Broth (Hi Media) - $0.8 \mathrm{~g}$, supplemented with $10 \% \mathrm{KCl}, 1.2 \% \mathrm{MgSO}_{4} .7 \mathrm{H}_{2} \mathrm{O}, 1 \mathrm{M} \mathrm{NaOH}, 1 \mathrm{M} \mathrm{Ca}\left(\mathrm{NO}_{3}\right)_{2}, 0.01 \mathrm{~m}$ $\mathrm{MnCl}_{2}, 1 \mathrm{mM} \mathrm{FeSO}$ ]. Sporulation efficiency was determined as the titer of heat-resistant spore versus the total spore counts in DSM broth. After $24 \mathrm{~h}$ of incubation in the DSM broth, viable counts were enumerated on Nutrient agar plates, prior and after the heat treatment (at $80^{\circ} \mathrm{C}$ and $65^{\circ} \mathrm{C}$ for $20 \mathrm{~min}$ ). Sporulation efficiency corresponds to the percentage of survivors

\section{i.e. no. of spores after heat treatment $\times 100$}

Total no. of spore in DSM broth

\subsection{Hemolysis Study}

Hemolytic nature of B.aerius \& B.cereus was studied using Super-imposed Blood Agar (SIBA) by spot inoculation [12]. The hemolytic isolate was subjected to serial sub culturing on nutrient agar slants for several passages and loss of hemolysis checked and confirmed for next 3 passages. Antimicrobial activity was also checked after loss of hemolysis.

\subsection{Acid and Bile Salt Tolerance}

Simulated Gastric juice was prepared by using $5 \mathrm{mg} / \mathrm{ml}$ of standard pepsin, filter sterilized and adjusted to $\mathrm{pH} 1.5,2.0,2.5$ and 3.0 Viability of the isolates was determination by CFU/ml after different periods of exposure (0min, 30min, 60min, 90min and $120 \mathrm{~min}$ in the simulated gastric juice) [7].

Intestinal juice was prepared by dissolving bile salts (1:1 Sodium cholate and sodium deoxycholate) of different concentrations $(0 \%, 0.5 \%, 1.0 \%$ and $2.0 \%)$ [13]. Viability was analyzed by same method as above.

\section{RESUlTS AND DisCUSSION}

\subsection{Temperature and pH Study}

Both the isolates in the present study were found to grow in the mesophilic range of temperatures between $25^{\circ} \mathrm{C}$ to $45^{\circ} \mathrm{C}$ (Fig 1). There was no growth observed for both the isolates at temperatures $10^{\circ} \mathrm{C}$ and $60^{\circ} \mathrm{C}$. Optimum growth of $B$ aerius was observed at $37^{\circ} \mathrm{C}$ while that of $B$. cereus at $45^{\circ} \mathrm{C}$.

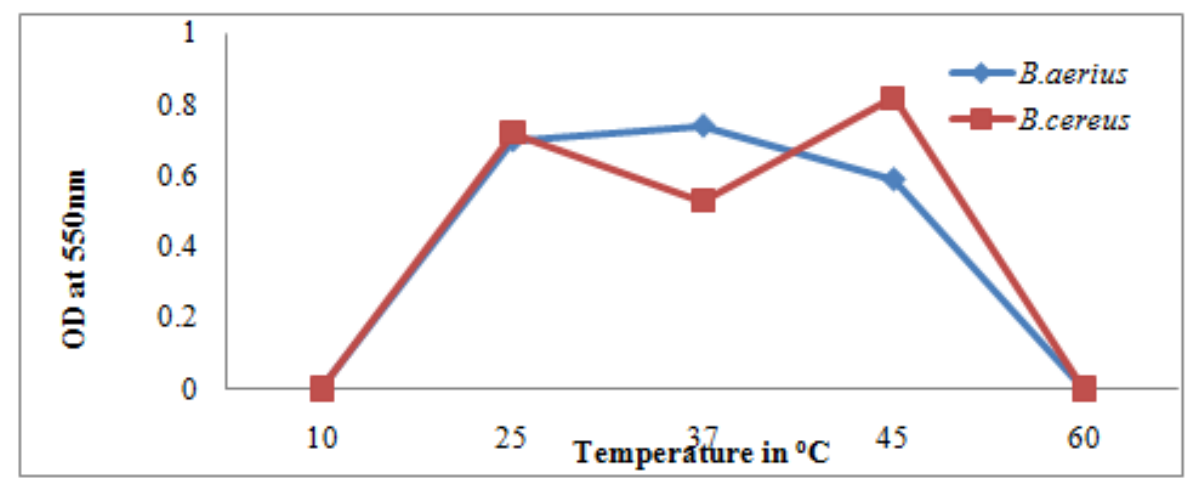

Fig1. Effect of temperature on growth of Bacillus isolates 
An interesting observation made in this study was that the $\mathrm{pH}$ tolerance of the isolates varied as the incubation temperatures changed (Fig 2). B.aerius, which has temperature optima of $37^{\circ} \mathrm{C}$, exhibited maximum growth at $\mathrm{pH}$ 6.0. However when the temperature of incubation was shifted to $45^{\circ} \mathrm{C}, \mathrm{pH}$ optima was shifted to 8.0. Similarly B.cereus has temperature optima of $45^{\circ} \mathrm{C}$ and $\mathrm{pH}$ optima of 6.0. As the incubation temperature is shifted to $37^{\circ} \mathrm{C}$, the $\mathrm{pH}$ optima changed to 10 .
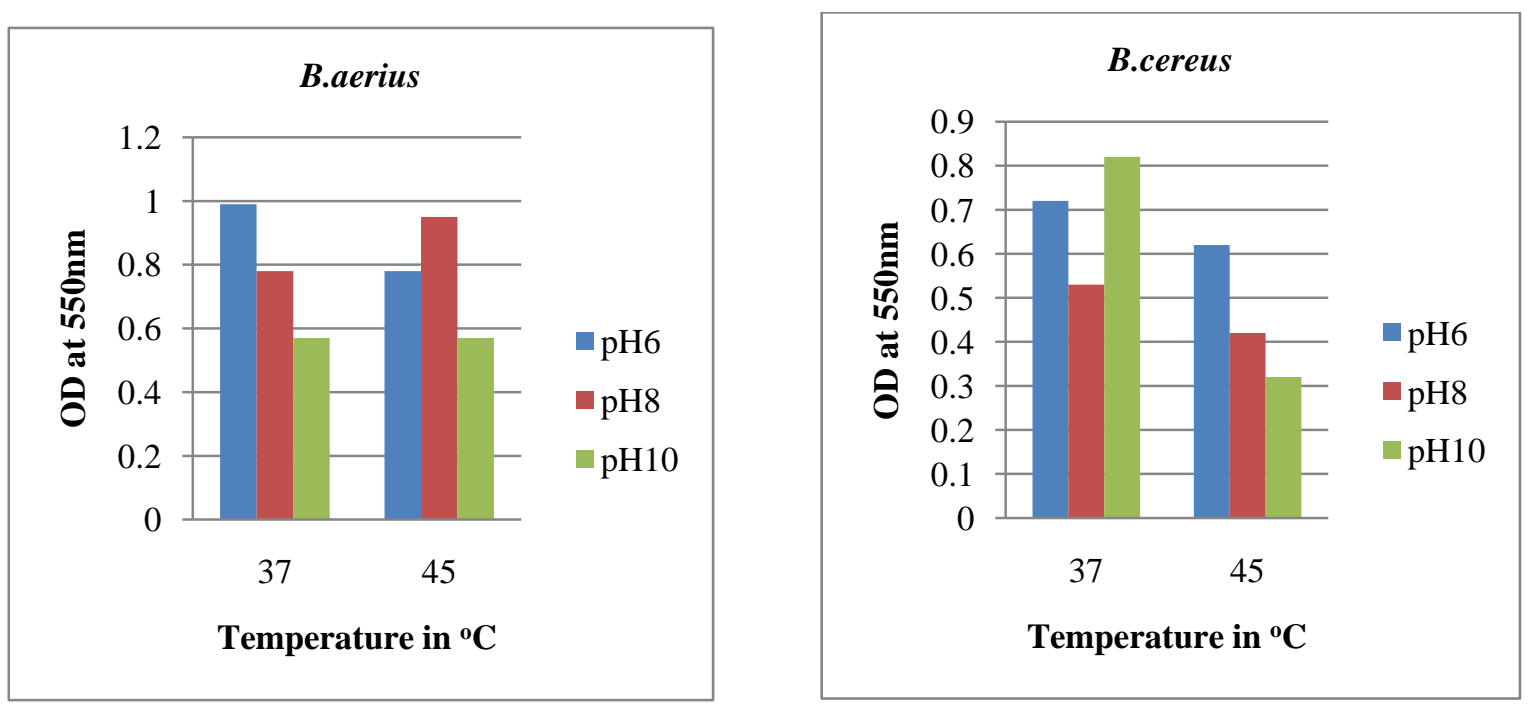

Fig2. Effect of pH on growth of Bacillus isolates

Bacillus species are known to grow at a wide $\mathrm{pH}$ range of 5 to 9 and some even at $\mathrm{pH}$ as low as 2 or as high as 10 [14]. The $\mathrm{pH}$ value in specific areas of the Gastrointestinal Tract helps in establishing a specific microbial population and also in turn affects the digestion and absorption of most nutrients. Most gut pathogens are found to grow at $\mathrm{pH}$ close to 7 or higher while commonly used beneficial probiotics grow in acidic $\mathrm{pH}$ [15]. The present study shows a distinct advantage of the two Bacillus species in gut environment as their $\mathrm{pH}$ optima falls near to or in the alkaline range thus enabling them to compete more effectively with the pathogens in the gut.

\subsection{Growth Curve}

Spores of Bacillus are said to be resistant to various chemical and physical factors [8], thus have an intrinsic resistance to the conditions of the gastrointestinal tract [16]. Various beneficial metabolites produced and factors by Bacillus species depends on the growth phase. The objective of this study is to know and understand the growth phases of the two isolates.

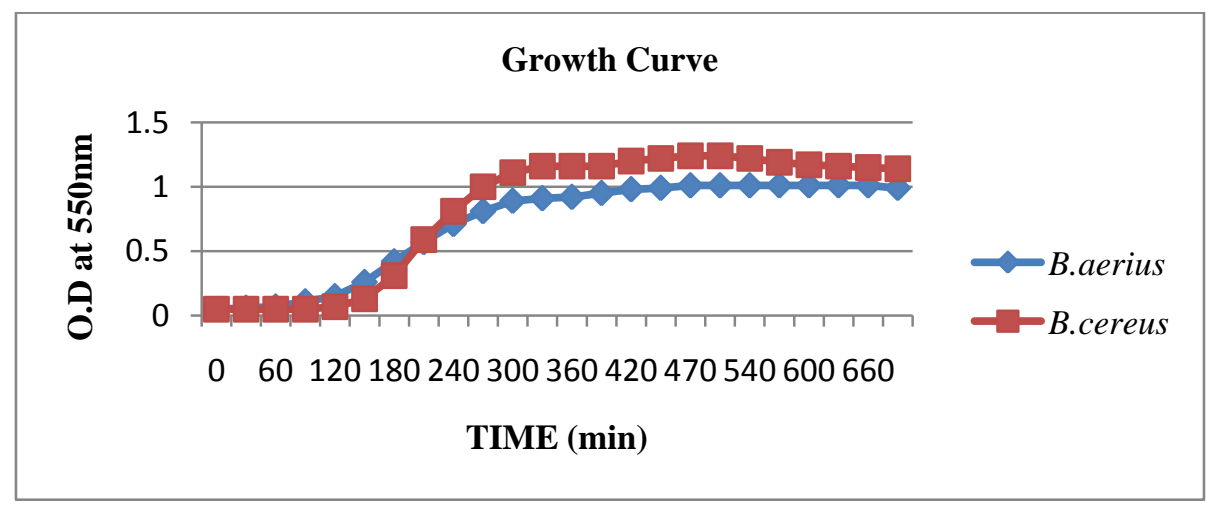

Fig3. Growth Curve

Endospores of Bacillus are formed when the vegetative cells pass out of the exponential phase and are eventually released as a free spore, which is usually as a result of nutrient depletion [17]. Sporulation is said to be depicted by the stationary phase, is initiated in Bacillus species when there is limitation of Carbon, Nitrogen or Phosphate [18]. The start of the stationary phase for every species varies from the type of media used to the utilization of these nutrient sources by those isolates. As per fig 3 it can be seen that the stationary phase for both the isolates starts at $300 \mathrm{~min}(5 \mathrm{~h})$ in. Sporulation takes place in seven stages and for the entire sporulation process it takes around 6-8 $\mathrm{h}$ in Bacillus subtilis [18]. B.aerius and B.cereus show stationary phase of more than $7 \mathrm{~h}$. 


\subsection{Sporulation Efficiency}

Spores continually monitor the surroundings for the presence of nutrition and they germinate and resume vegetative growth in the presence of appropriate nutrients. Spore formation thus represents a strategy by which the bacterial cell protects itself temporarily from nutrition deficiency or unfavorable local conditions by dormancy [19]. In order to understand and determine the ability of spore formation, both the Bacillus isolates were exposed to a nutrient depleted medium which contains low concentrations of organic $\mathrm{C}$ and $\mathrm{N}$ source leading to spore formation.

Table1. Sporulation efficiency

\begin{tabular}{|c|c|c|c|}
\hline \multirow[t]{2}{*}{ ISOLATE } & \multicolumn{2}{|c|}{ No. of spores capable of germination $/ \mathrm{ml}$} & \multirow[t]{2}{*}{ Sporulation efficiency $\%$} \\
\hline & $\begin{array}{l}\text { Before heat } \\
\text { Treatment }\end{array}$ & $\begin{array}{l}\text { After heat } \\
\text { Treatment }\end{array}$ & \\
\hline B.aerius $\left(80^{\circ} \mathrm{C}\right)$ & $2.07 \times 10^{7}$ & $0.8 \times 10^{7}$ & 38.6 \\
\hline B.aerius $\left(65^{\circ} \mathrm{C}\right)$ & $2.07 \times 10^{7}$ & $2.13 \times 10^{7}$ & 107.7 \\
\hline B.cereus $\left(80^{\circ} \mathrm{C}\right)$ & $3.8 \times 10^{9}$ & - & - \\
\hline B.cereus $\left(65^{\circ} \mathrm{C}\right)$ & $3.8 \times 10^{9}$ & $3.89 \times 10^{9}$ & 102 \\
\hline
\end{tabular}

One of the most important factors that determine the heat resistance of spores is its sporulation temperature. Bacterial spores are usually more heat resistant when they are formed at higher temperatures [20]. A marked increase in the sporulation efficiency was observed when temperature of incubation was shifted from $80^{\circ} \mathrm{C}$ (38\% efficiency) to $65^{\circ} \mathrm{C}$ (100\% efficiency) in case of B. aerius, indicating that the spores of B. aerius are able to sustain a temperature of $80^{\circ} \mathrm{C}$. B.cereus failed to show any sporulation at $80^{\circ} \mathrm{C}$ but could sporulate efficiently at $65^{\circ} \mathrm{C}(100 \%)$ [10]. There is an optimum temperature for growth and thus also highest temperature for thermal resistance of spores is set, above or below which the thermal resistance of the spores is diminished [21]. With respect to our observations and the above arguments, $65^{\circ} \mathrm{C}$ was found to be the optimum temperature for thermal resistance of the spores for both the isolates. Also the spores of $B$. aerius are more heat resistant than the spores of B.cereus.

\subsection{Hemolytic Study}

Hemolytic activity on blood agar plate is generally used for identifying pathogenic microorganisms [22]. B.cereus was non hemolytic while B. aerius, which was initially hemolytic was rendered non hemolytic by serial sub culturing on Nutrient agar slants [11]. Loss of hemolysis after third sub culture, retention of non-hemolytic character after three subsequent passages and retention of probiotic attributes after subcultures was confirmed.

\subsection{Acid And Bile Salt Tolerance}

In order to survive in the gastrointestinal tract, a probiotic must be resistant to the salivary enzyme, gastric acid and bile, and able to establish itself in the intestinal microbiota [23]. According to the guidelines of the evaluation of probiotic organisms, reported by a joint FAO/WHO working group, two of the currently most widely used in vitro tests are resistance to gastric acidity and bile compounds based on both survival and growth studies [24].
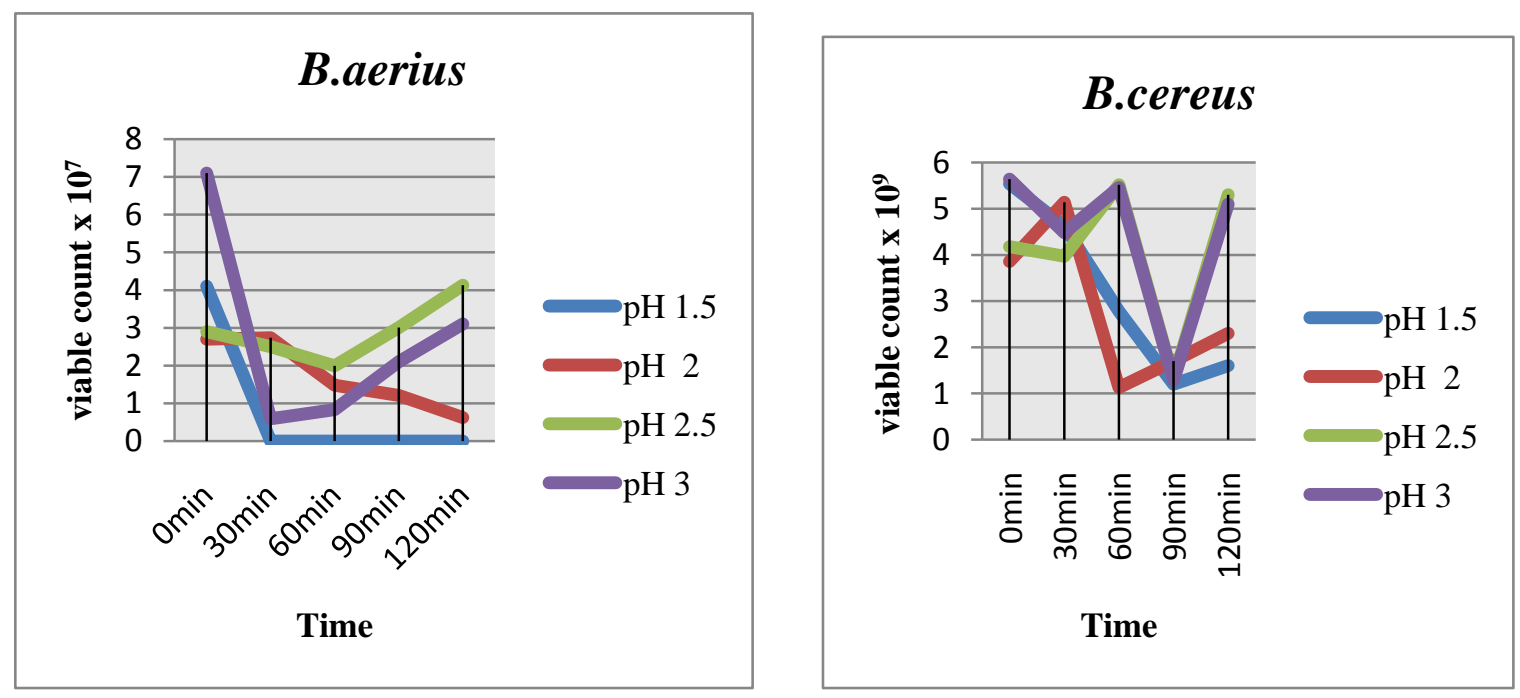

Fig4. a) Acid tolerance 


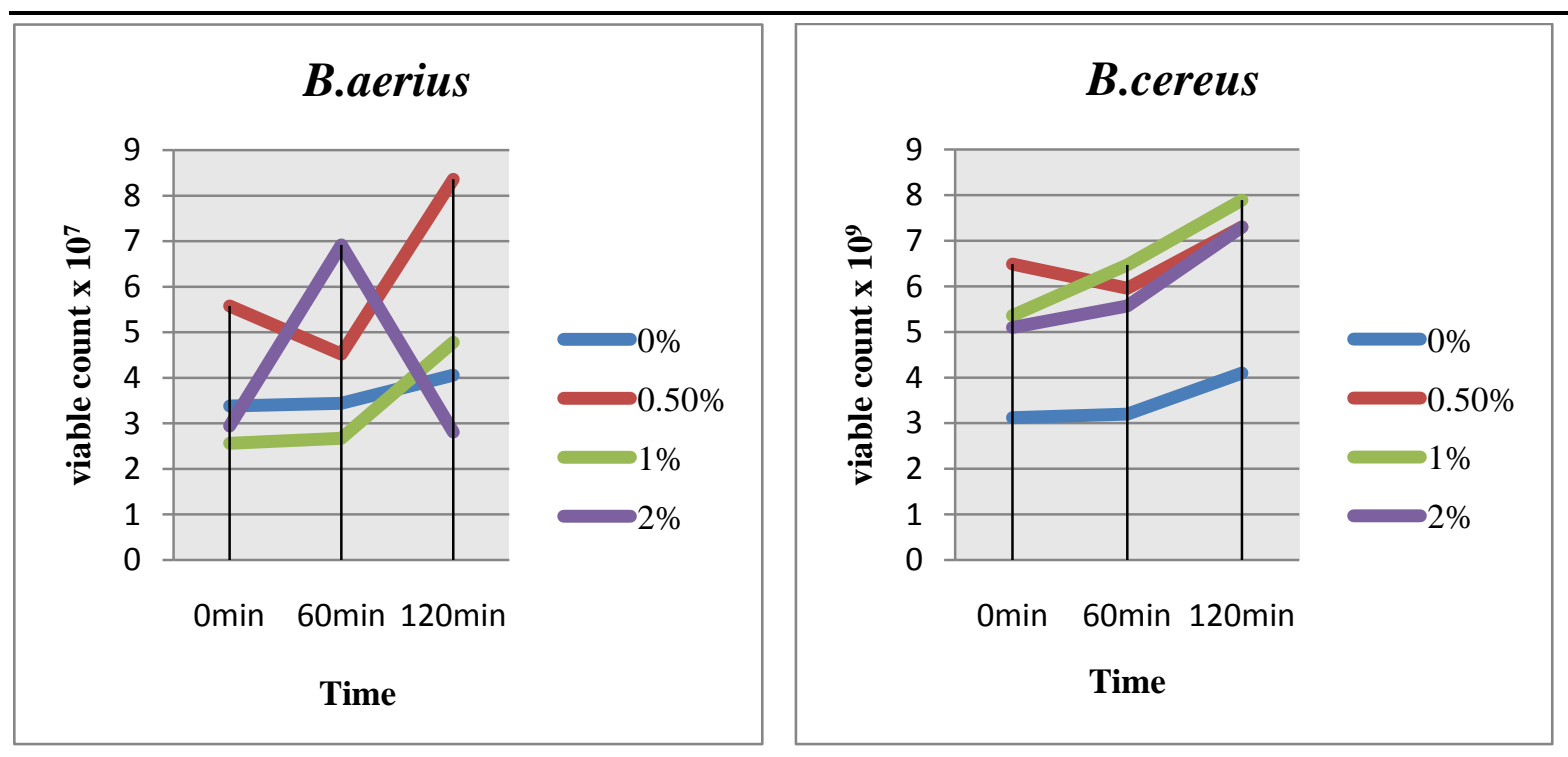

Fig4. b) Bile tolerance

B. aerius was found to tolerate $\mathrm{pH} 2-3$, while could not tolerate $\mathrm{pH} 1.5$ beyond $30 \mathrm{~min}$. At the survived $\mathrm{pH}$ values, there was a characteristic decrease in viable numbers for initial 30-60 min and a further increase up to $120 \mathrm{~min}$ exposure. This explains the period of adaptation for B. aerius with survival and germination capabilities at the said $\mathrm{pH}$ values [7]. Whereas in simulated intestinal juice of concentrations $0.5 \%$ and $1 \%$ the spore count was found to increase after an adaptation period of 60 min and a decrease in spore count at $2 \%$ concentration was observed.

B. cereus count decreased at $\mathrm{pH} 1.5$ and 2 indicating poor survival. After a period of adaptation (30min) at $\mathrm{pH} 2.5$ and 3 , the count increased followed by a distinct decrease in the count indicating that the spores are able to survive, though the nature of the spore adaptability could not be understood clearly after $60 \mathrm{~min}$ of incubation in gastric juice. In simulated intestinal juice, an increase in spore counts was observed at $0.5 \%, 1 \%$ and $2 \%$ with an adaptation period of 60 min indicating that the spores could survive and germinate at higher bile salt concentrations.

It is evident from the above results that the spores of both the isolates could tolerate acidity in the range of $\mathrm{pH} 2-2.5$ with the ability of $B$. aerius spores to germinate at $\mathrm{pH} 3$ indicating the ability to survive the gut and germinating to exert their functional properties as a probiotic. Also the spores could tolerate a higher bile salt concentration, with an ability to germinate at lower concentration.

\section{Conclusion}

The present study characterizes soil isolates B. aerius and B. cereus, capable of sporulating at $65^{\circ} \mathrm{C}$ in a nutrient deficient environment with $100 \%$ efficiency. The optimum temperature and $\mathrm{pH}$ for growth of B.aerius was found to be $37^{\circ} \mathrm{C}$ and 6 respectively, whereas for B.cereus $45^{\circ} \mathrm{C}$ and 6 respectively. The spores of both the isolates were found to tolerate acidity as low as $\mathrm{pH} 2$ and bile salt concentration up to $2 \%$ with an ability to germinate at $\mathrm{pH} 3$ and at lower bile salt concentrations by $B$. aerius. Considering the various parameters studied, both the Baciilus isolates can be considered as probable probiotic candidates.

\section{REFERENCES}

[1] Sullivan A. \& Nord C.E. (2002): Probiotics in human infections. Journal of Antimicrobial Chemotherapy. Vol.50 (5), p.625-627.

[2] Rambaud Jean - Claude, Bouhnik Yoram, Marteau Philippe \& Pochart Philippe (1993): Manipulation of the human gut flora. Proceedings of the Nutritional Society. 52, p. 357-366.

[3] Duc Le H., Hong Huynh A., Barbosa Teresa M., Henriques Adriano O., \& Cutting Simon M. (2004): Characterization of Bacillus Probiotics available for human use. Applied And Environmental Microbiology, Vol.70, No.4, p.2161-2171.

[4] Sanders ME (2000): Considerations for use of probiotic bacteria to modulate human health. Journal of Nutrition. 130, p. 384S-390S.

[5] Simen M. Kristoffersen, Solveig Ravnum, Nicolas J. Tourasse, Ole Andreas Økstad, AnneBrit Kolstø and William Davies (2007): Low Concentrations of Bile Salts Induce Stress Responses and Reduce Motility in Bacillus cereus ATCC 14570. Journal of Bacteriology. 189(14), p. 5302-5313. 
[6] Suparna Dugal and Olivia Rao (2011): Enhancement of acid tolerance of entrapped probiotic bacteria by polyoxyethylene (80) sorbitan monooleate. Journal of Chemical and Pharmaceutical Research. 3(4): 122-128.

[7] Both Emese, György Éva, Kibédi-Szabó Csaba Z., Tamás Éva, Ábrahám Beáta, Miklóssy Ildikó, Lányi Szabolcs (2010): Acid and bile tolerance, adhesion to epithelial cells of probiotic microorganisms. U.P.B. Scientific Bulletin, Series B. 72(2), p. 37-44.

[8] Nicholson W. L., N. Munakata, G. Horneck, H. J. Melosh, and P. Setlow (2000): Resistance of Bacillus endospores to extreme terrestrial and extraterrestrial environments. Microbiology and Molecular Biology Reviews. 64:548-572.

[9] A. Rodríguez-Lozano, M. Campagnoli, K. Jewel, F. Monadjemi and J.E. Gaze (2010): Bacillus spp. thermal resistance and validation in soups. Current Research, Technology and Education Topics in Applied Microbiology and Microbial Biotechnology, A. Mendez-Vilas Ed. 537-544. http://www.formatex.info/microbiology2/537-544.pdf

[10] Barbosa M. Teresa, Serra R. Cla'udia, La Ragione M. Roberto, Woodward J. Martin and Henriques O. Adriano (2005): Screening for Bacillus Isolates in the Broiler Gastrointestinal Tract. Applied and Environmental Microbiology. 71(2), p. 968-978.

[11] Lavanya Ananthanarayanan and Aparna Dubhashi (2015): Characterization of Bacillus species isolated from natural sources for probiotic properties. Int.J.Curr.Biotechnol. 3(8): 22-27.

[12] ElSersy Nermeen A. and Mohamed Eman A. H. (2011): Biochemical and molecular characterization of hemolytic Bacillus licheniformis strains isolated from shrimp and clam aquacultures. African Journal of Microbiology Research. 5(14), p. 1830-1836.

[13] Cenci G., Trotta F. and Caldini G. (2006): Tolerance to challenges miming gastrointestinal transit by spores and vegetative cells of Bacillus clausii. Journal of Applied Microbiology. 101, p. $1208-1215$.

[14] Peter H. A. Sneath (1986): Bergey's Manual of Systematic Bacteriology, Volume 2, $8^{\text {th }}$ Edition. Section 13: Endospore-forming Gram-Positive Rods and Cocci.

[15] Rahmani H.R., Speer W. and Modirsanei M. (2005): The Effect of Intestinal pH on Broiler Performance and Immunity. p. 338-340. www.cabdirect.org/abstracts/20073279610.

[16] B. Sa'nchez, S. Arias, S. Chaignepain, M. Denayrolles, J. M. Schmitter, P. Bressollier and M. C. Urdaci (2009): Identification of surface proteins involved in the adhesion of a probiotic Bacillus cereus strain to mucin and fibronectin. Microbiology. 155, p. 1708-1716.

[17] Todar Kenneth (2005): The Genus Bacillus. Todar's online Textbook of Bacteriology. http://textbookofbacteriology.net/Bacillus_2.html

[18] Ralph A. Slepecky and H. Ernest Hemphill (2006): Chapter 1.2.16- The Genus BacillusNonmedical. Prokaryotes. 4: 530-562. DOI: 10.1007/0-387-30744-3_16. www.ic.ucsc.edu/ saltikov/bio1191/readings/prokaryotes/Bacillus.pdf

[19] Nicholson W.L. and Setlow P (1990): Sporulation, germination and Outgrowth. In C.R. Harwood and S.M. Cutting (Eds.), Molecular Biological Methods for Bacillus (p. 391-450). Chichester, UK :John Wiley \& Sons Ltd.

[20] Palop Alfredo, Pilar Manas and Santiago Condon (2007): Sporulation Temperature and Heat Resistance of Bacillus spores: A Review. Journal of Food Safety. 19(1), p. 57-72. http://onlinelibrary.wiley.com/doi/10.1111/j.1745-4565.1999.tb00234.x/abstract

[21] El-Bisi Hamed and Ordal John (1956): The effect of Sporulation Temperature on the Thermal Resistance of Bacillus coagulans Var. Thermoacidurans. Journal of Bacteriology. 71(1), p. 1016. http://www.ncbi.nlm.nih.gov/pmc/articles/PMC357730

[22] Chantharasophon K., Warong T., Mapatsa P. and Leelavatcharamas V. (2011): High potential Probiotic Bacillus species from Gastro-intestinal tract of Nile Tilapia (Oreochromis niloticus). Biotechnology.

[23] Sansawat Ananthaya and Thirabunyanon Mongkol (2009): Anti-Aeromonas hydrophila activity and characterization of novel probiotic strains of Bacillus subtilis isolated from the gastrointestinal tract of giant freshwater prawns. Maejo International Journal of Science and Technology. 3(01), p. 77-87.

[24] Vizoso Pinto MG, Franz CMAP, Schillinger U, Holzapfel WH (2006): Lactobacillus spp with in vitro probiotic properties from human faeces and traditional fermented products. International Journal of Food Microbiology. 109: 205-214. 